\title{
LUM wt Allele
}

National Cancer Institute

\section{Source}

National Cancer Institute. LUM wt Allele. NCI Thesaurus. Code C118987.

Human LUM wild-type allele is located in the vicinity of 12 q21.33 and is approximately 9 $\mathrm{kb}$ in length. This allele, which encodes lumican protein, plays a role in the structure of the extracellular matrix. 